\title{
CHEMOSPHERE
}

\section{A model for evaluation of the phytoavailability of trace elements to vegetables under the field conditions}

\author{
Xiao-ping Wang, Xiao-quan Shan *, Shu-zhen Zhang, Bei Wen \\ Research Center for Eco-Environmental Sciences, Chinese Academy of Sciences, P.O. Box 2871, Beijing 100085, China
}

Received 3 July 2003; received in revised form 20 November 2003; accepted 1 December 2003

\begin{abstract}
Currently, several single extraction methods are used for the evaluation of the phytoavailability of metals using pot experiments. A systematic comparison, however, is lacking. It is especially true for the field studies. This study was to investigate the phytoavailability of trace elements to vegetables grown on metal-contaminated soils under the field conditions. All soils collected were typical calcareous soils in northern China. Four frequently used methods using $\mathrm{CaCl}_{2}$, diethylenetriaminepentaacetic acid (DTPA), $\mathrm{CH}_{3} \mathrm{COOH}$, and water as extractants were compared for phytoavailability. The concentrations of metals extracted by these four extraction methods ranged from 3.42 to $815,1.51-$ 6965, 0.732-24473, 0.688-7863, 0.246-685, 1.99-5337 0.203-4649 ng/g for $\mathrm{Cr}, \mathrm{Ni}, \mathrm{Zn}, \mathrm{Cu}, \mathrm{Cd}, \mathrm{Pb}$ and REEs, respectively. Simple correlation analysis indicated that a significant correlation $\left(\mathrm{Cr}: r=0.5411^{* *}\right.$; $\mathrm{Zn}: r=0.6352^{* *}$; $\mathrm{Cd}$ : $r=0.6979^{* *} ; \mathrm{Pb}: r=0.5537^{* *}$ and REEs: $r=0.5185^{* *}-0.6684^{* *}$ ) was observed between the $\mathrm{CaCl}_{2}$-extractable metals in soil solution and that in Chinese cabbage. In addition, soil $\mathrm{pH}$, organic matter $(\mathrm{OM})$, and cation exchange capacity (CEC) also affect the phytoavailability. An empirical model was developed to express the combined effect of soil properties on the phytoavailability. The stepwise multiple regression analysis demonstrated that the phytoavailability of trace elements strongly correlated with the extractable fraction by $\mathrm{CaCl}_{2}$, total metal concentration in soils, and soil $\mathrm{pH}$, OM, CEC. This model can describe approximately $75-95 \%$ of the variability of metal uptake and the $r^{2}$ values ranged from $0.741^{* *}$ to $0.954^{* *}$, which were much better than the single correlation analysis. For celery and cole, a strong correlation was obtained for $\mathrm{Cr}, \mathrm{Ni}, \mathrm{Zn}, \mathrm{Cu}, \mathrm{Cd}, \mathrm{La}, \mathrm{Ce}, \mathrm{Pr}$ and $\mathrm{Nd}$. For spinach and Chinese cabbage, however, a positive correlation was only observed for 1 and 3 metals, respectively. Generally, the developed empirical model can integrate the combined effects of soil properties, extractable metal fractions in soil solutions and plant species on the phytoavailability of metals to vegetables in the field conditions.
\end{abstract}

(C) 2003 Elsevier Ltd. All rights reserved.

Keywords: Model; Vegetables; Phytoavailability; Soil properties

\section{Introduction}

Consumption of vegetables is one of the most important pathways by which heavy metals enter the

\footnotetext{
${ }^{*}$ Corresponding author. Tel.: +86-10-6292-3560; fax: +8610-6292-3563.

E-mail address: xiaoquan@mail.rcees.ac.cn (X.-q. Shan).
}

food chain. Both the farmland and urban environment often suffer from the metal contamination due to the irrigation with wastewater and traffic emission. Therefore, human exposure to contaminations of soils and vegetables is a matter of health concern. In soil-plant system, the risk assessments often include physicochemical characteristics of soils (e.g. organic matter content, $\mathrm{pH}$, and $\mathrm{CEC}$ ). However, these risk assessments are often erroneous and unrealistic based on the availability of metals in freshly spiked soils or pot 
experiments or the crop plants. Soil is a heterogeneous system, which shows significant variability and may be influenced by external factors such as climate and human agricultural practices. A survey of literature shows there is no report on the phytoavailability of metals in soils to vegetables under the field conditions.

It is common conception nowadays that the total concentrations of metals in soils are not a good indicator of phytoavailability, or a good tool for potential risk assessment, due to the different and complex distribution patterns of metals among various chemical species or solid phases (Chen et al., 1996). The experimentally defined chemical procedures have been applied to identify plant-available forms of trace metals in soils. The most widely used methods for the evaluation of the availability of metals in soils are single extraction (Lindsay and Norvel, 1978; Leschber et al., 1985) and sequential extraction methods (Tessier et al., 1979; Ure et al., 1993). However, the sequential extraction methods are rather laborious and time consuming. Among single extraction methods, $\mathrm{CaCl}_{2}$ and DTPA were the most widely used extractants (Novozamsky et al., 1993; Houba et al., 1996). DTPA (containing 0.01 $\mathrm{M} \mathrm{CaCl}_{2}$, $\mathrm{pH} 7.3$ and $0.1 \mathrm{M}$ triethanolamine) is suitable for calcareous soils, as it is buffered at a $\mathrm{pH} 7.3$ and therefore prevents $\mathrm{CaCO}_{3}$ from dissolution and releases of occluded metals (Lindsay and Norvel, 1978). The $\mathrm{CH}_{3} \mathrm{COOH}$ is the first step of a three-stage sequential extraction procedure recommended by European Community Bureau of Reference (BCR) (Ure et al., 1993). The extraction with water is to simulate the metal distribution equilibriums of metals in soil pore water.

It has long been recognized that the soluble, exchangeable and loosely adsorbed metals are quite labile, and hence more available for plants (KabataPendias, 1993). Therefore, in order to assess the environmental risk and the phytoavailability of metals, efforts should be concentrated on the measurements of these available fractions. In this context, the phytoavailability of metals in soils to vegetables has been estimated by above-mentioned four single-extraction methods in order to give ideas on mechanisms responsible for metal uptake. Numerous literatures have reported that the soil characteristics can affect the phytoavailability of metals (Mcbride et al., 1981). The aim of the present study was to evaluate the combined effect of soil properties on the phytoavailability. Therefore, an empirical model was developed to correlate the metal phytoavailability with common soil properties and with metal concentrations in the extractable soil fractions obtained by the above-mentioned extraction methods. This allows the assessment of the potential abilities of the vegetables to mobilize or to accumulate metals from soils. The implication to human health can be evaluated by estimating the consumption of vegetables growing on the metal-contaminated soil.

\section{Materials and methods}

\subsection{Soils}

All sampling sites were concentrated in northern China. Surface soil samples $(0-10 \mathrm{~cm})$ were collected from the vegetable yard of 14 cities. These soils were calcareous soil and are affected by different anthropogenic sources of pollution: mine works, steel factory and highway emission. Among these sample sites, Yantai, Dalian and Beidaihe are tour cites; Beijing is the capital of China; Tianjing, Huludao, Yingkou, Zhengzhou, Jinan, Linyi and Xingxiang are all industrial cities. Fuyang and Hanzhong are small cities with small factories. The soil loosely adhered to roots were gently shaken off and the rhizosphere soil adhering to roots were separated by hands. Five to six grams of rhizosphere soils were sampled. One portion of the moist rhizosphere soils was stored in refrigerator for the metal fraction extraction and another portion was air-dried and sieved through a 2-mm nylon mesh for total metal analysis and water content measurement.

\subsection{Plants}

Four common vegetables, Chinese cabbage [Brassica compestris L. ssp. pekinensis (lour) Olsson], spinach (Spinacia oleracea L.), celery (Apium graveolens) and cole [Brassica cumpestris L. ssp. chinensis (L.) Makino, var. communis Tsenetlee] were collected from vegetable garden and three crops of each species were randomly selected. All selected plants were 6-8-week growth period and maturity. The crop quality was good for all vegetables. The vegetables were separated into roots and leaves (including stems). Roots and leaves of different vegetables were successively washed with tap water first to remove all visible fine soil particles and then with distilled water. The vegetables were oven-dried at $60{ }^{\circ} \mathrm{C}$ for $48 \mathrm{~h}$ before metal determination.

\subsection{Characteristics of soils}

Soil pH was measured using 1:2.5 (w:v) soil/de-ionized water ratio. Organic matter was determined by the Walkley-Black procedure (Nelson and Sommers, 1982). Cation exchange capacity (CEC) was determined by the method described by Rhoades (1982). These soil properties are listed in Table 1.

\subsection{Single soil extraction}

The operating schemes of all single-extraction methods employed in this study were consistent with the corresponding literatures (Lindsay and Norvel, 1978; Novozamsky et al., 1993; Ure et al., 1993; Houba et al., 
Table 1

Characteristics of soils

\begin{tabular}{lllc}
\hline Soil no. & OM $(\%)$ & $\mathrm{pH}$ & CEC $(\mathrm{meq} / 100 \mathrm{~g})$ \\
\hline 1: Beijing & 3.58 & 7.64 & 92.3 \\
2: Beidaihe & 0.899 & 7.09 & 109 \\
3: Tianjing & 4.27 & 7.25 & 51.6 \\
4: Huludao & 2.12 & 7.35 & 53.4 \\
5: Yingkou & 2.19 & 6.66 & 51.6 \\
6: Dalian & 4.36 & 6.91 & 62.9 \\
7: Zhengzhou & 1.09 & 6.99 & 76.8 \\
8: Jinan & 5.68 & 7.05 & 112 \\
9: Linyi & 1.68 & 6.55 & 56.3 \\
10: Yantai & 0.705 & 6.32 & 48.6 \\
11: Xinxiang 1 & 1.28 & 6.65 & 124 \\
12: Xinxiang 2 & 4.56 & 7.50 & 133 \\
13: Fuyang & 1.05 & 7.25 & 76.1 \\
14: Hanzhong & 1.56 & 6.89 & 30.2 \\
\hline
\end{tabular}

1996). One gram of moist rhizosphere soil was used for metal fractionation.

\subsection{Determination of trace elements}

The dried soil samples were used for the determination of metals. A portion of $0.1000 \mathrm{~g}$ soil was digested with $3 \mathrm{ml} \mathrm{HNO} / 1 \mathrm{ml} \mathrm{HClO}_{4} / 1 \mathrm{ml} \mathrm{HF}$ (Zhang and Shan, 1997). For vegetables $0.3000 \mathrm{~g}$ of roots or leaves were digested with $1 \mathrm{ml} \mathrm{HNO} / 1 \mathrm{ml} \mathrm{HClO}_{4}$ only. The concentrations of trace elements after sample digestion were determined by ICP-MS (Plasma Quad III, UK). A solution of ${ }^{115} \mathrm{In}$ at $20 \mathrm{ng} / \mathrm{ml}$ in $1 \% \mathrm{HNO}_{3}$ was used as an internal standard to compensate for matrix suppression and signal drifting during metal determination. The detailed operating condition of ICP-MS was reported previously (Li et al., 1998).

All reagents used were of analytical reagent grade or better. Statistical analysis was performed by use of SPSS software.

\section{Results and discussion}

\subsection{Characteristics of soils}

As shown in Table 1, soil $\mathrm{pH}$ values ranged from 6.32 to 7.64. For soil samples collected from Linyi, Yantai and Xinxiang (Table 1) the soil $\mathrm{pH}$ are slightly acidic. The Xinxiang soil 2 was irrigated with wastewater and its soil $\mathrm{pH}$ was slightly higher than $\mathrm{pH}$ of Xinxiang soil 1 with no wastewater irrigation. The organic matter contents varied from $0.7 \%$ to $5.6 \%$ among these soils, suggesting that the fertilizer levels in these soils were different. This discrepancy may influence the growth of vegetables and further influence the phytoavailability of metals. It was noticeable that Xinxiang soil 2 has higher
OM content than that of Xinxiang soil 1, which means that wastewater irrigation significantly increased the organic matter content in soils. CEC values of these soils were ranged from 48.6 to $112 \mathrm{mmol} / \mathrm{kg}$. Xinxiang soil 1 and Xinxiang soil 2 have quite similar CEC values, indicating that the wastewater irrigation did not significantly change the cation exchange capacity of soils.

\subsection{Soil contamination status of heavy metals}

Total metal contents in soils (mg/kg, dry mass) are presented in Table 2. In addition, Table 3 lists the critical limits of soil metal concentrations of China and Denmark (Wang et al., 2001a,b; Lise et al., 2002) and the average values of USA, Japan and UK. The critical limits were defined as the values above which the toxicity was considered to occur. Compared the metal contents in Chinese soils with the critical limits and average content levels, it was quite clear that slight contamination of $\mathrm{Cd}, \mathrm{Pb}$ and $\mathrm{Cu}$ was occurred in several locations in northern China.

Generally, the soil heavy metal contaminations in north China were fortunately not so severe although the contamination levels were more or less higher than that in USA, but quite similar to that in Japan and Britain. Based on the critical limits, all sampled soils can be divided into uncontaminated soils, slightly contaminated soils and medium contaminated soils. In the uncontaminated soils (Dalian, Yantai, Fuyang, Hanzhong), the concentrations of metals were below the soil quality criteria. In Beijing, Zhengzhou, Jinan, Xinxiang 2 soils, the concentrations of $\mathrm{Cd}$ and $\mathrm{Pb}$ were close to the advisory intervals, whereas the concentrations of the remaining metals were below the soil quality criteria. In the contaminated soil (Beidaihe, Tianjing, Huludao, Linyi), the mean concentrations of heavy metals were above the criteria limit of Chinese EPA. For example, Linyi soil has much higher copper content $(239 \mathrm{mg} / \mathrm{kg}$, dry mass), nickel content ( $73.9 \mathrm{mg} / \mathrm{kg}$, dry mass) than other soils, which was above the critical range. The reason for the higher copper, nickel levels was ascribed to a large copper-nickel mine located there and it may contribute to this pollution problem. Up to $4 \mathrm{mg} / \mathrm{kg}$ of soil $\mathrm{Cd}, 200 \mathrm{mg} / \mathrm{kg}$ of soil $\mathrm{Pb}$ were detected in Huludao, a small city of Liaoning Province of China, where several large smelting factories and rock oil factories were located there. In Tianjing city, especially in BeijingTianjin-Tangshan area, wastewater irrigation caused soil contamination problem. Because the soils sampled are the surface soil $(0-10 \mathrm{~cm})$, soil $\mathrm{Pb}$ content was enhanced by atmospheric deposition in the vicinity of heavy industry, or the traffic emission. This is the reason for the large-scale $\mathrm{Pb}$ pollution in the investigated soils.

Unavoidably, some heavy metals deposited in the sludge were transferred to soils simultaneously. Xinxiang soil 2 has higher metal concentration $(\mathrm{Cr}, \mathrm{Cd}$ and 


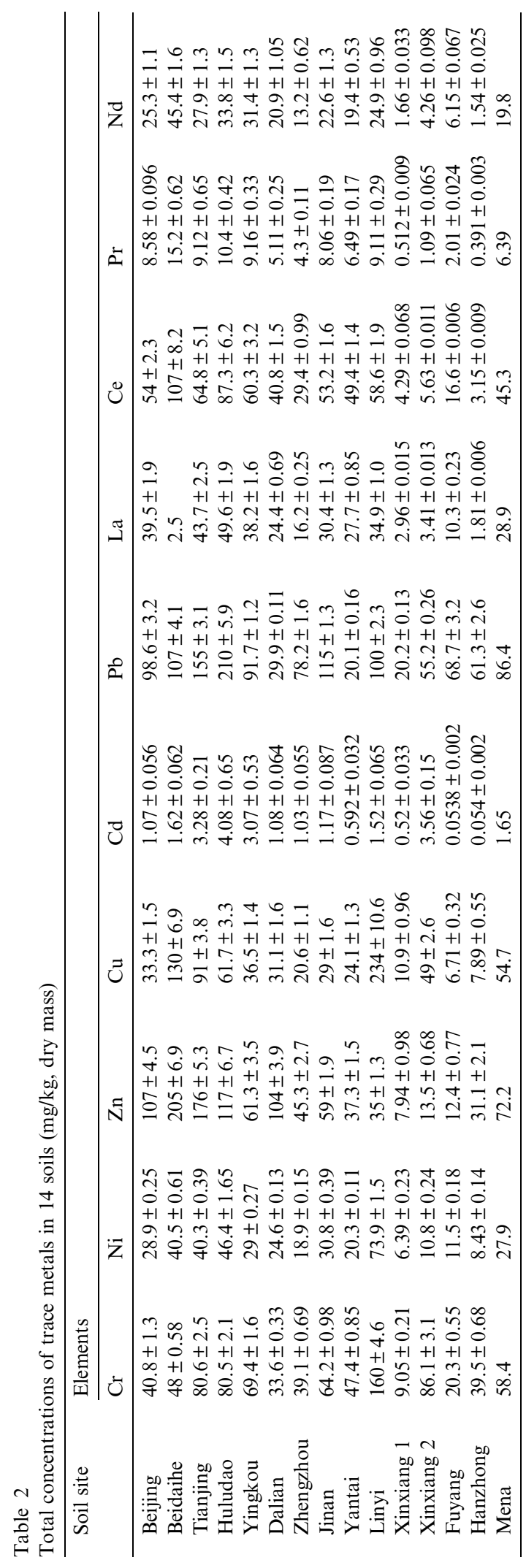

$\mathrm{Pb}$ ) than Xinxiang soil 1 . This was an evidence for the possibility of sewage contamination. Long-term application of metal-containing chemicals, such as Cd-containing phosphate fertilizers, $\mathrm{Pb}$-, and $\mathrm{Zn}$-containing pesticides, in agriculture could also result in soil contamination (McGrath, 2000). Wang et al. (2001a) have investigated the current status of soil contamination with heavy metals and sources of pollutants. Their investigation demonstrated that metal-containing agrochemical application in agriculture, e.g. Cd-abundant phosphates and the untreated electric planting wastewater irrigation usually lead to the elevated $\mathrm{Cd}$ content in soils.

\subsection{BCF values of vegetables}

BCF values were always used to describe the accumulation of chemicals in organisms, especially, those live in contaminated environments. BCFs were used to relate pollutant residues in organisms to the pollutant concentration in the environment. The BCF value can be calculated based on the ratio of metal concentrations in plants to soil. In our experiment, we considered heavy metals in vegetable leaves as the absorbed metal amounts or heavy metal residues in plants (Krishnamurti and Naidu, 2002). BCF values of heavy metal for four vegetables in uncontaminated soils, slightly contaminated soils and medium contaminated soils are shown in Fig. 1. Our experimental results indicated that the BCF values of all four vegetables decreased with increasing metal contamination in soil, especially for the more mobile metals $(\mathrm{Cd}$ and $\mathrm{Zn})$, for which the highest $\mathrm{BCF}$ values were found. This fact was observed by Lise et al. (2002). The high BCF values may exert potential risk to human health. There were two possible reasons for the interpretation why BCF values decreased with increasing soil contamination. One possible reason was that the self-adjusting of plants plays an important role on sequestering the metals in their roots. Only small amounts of metals are translocated to the up-ground parts of plants. In slightly contaminated soils, plants grow well and the metal concentration in plant leaves is at a similar level to or higher than that grown on clean soils. However, the corresponding metal contents of soils are much higher than the clean soil, and hence the BCF values of plants grown on slightly contaminated soils were decreased. Another possible reason is that plants grow badly on the contaminated soils. It is especially true on the heavily contaminated soil, plants become blasted and gradually die. In this case, because of the bad living condition, the metal uptake ability by plants was weakened, and the metal content in plant leaves was decreased. On the contrary, the corresponding metal content of soils was quite high, so the BCF values of plants in heavily contaminated soils were significantly decreased. All vegetables investigated in this 
Table 3

The critical limit and average level of metals in soils ( $\mathrm{mg} / \mathrm{kg}$, dry mass)

\begin{tabular}{|c|c|c|c|c|c|c|}
\hline \multirow[t]{3}{*}{ Elements } & \multicolumn{3}{|c|}{ Critical limit of metals in soils } & \multicolumn{3}{|c|}{ Average level of metals in soils } \\
\hline & \multicolumn{2}{|l|}{ China } & \multirow{2}{*}{$\begin{array}{l}\text { Denmark } \\
\text { Background soils }\end{array}$} & \multirow[t]{2}{*}{ USA } & \multirow[t]{2}{*}{ Japan } & \multirow[t]{2}{*}{ Britain } \\
\hline & $\begin{array}{l}\text { Cultivated } \\
\text { soils }\end{array}$ & $\begin{array}{l}\text { Background } \\
\text { soils }\end{array}$ & & & & \\
\hline $\mathrm{Cr}$ & 200 & 35 & 50 & 54 & 41.3 & 84 \\
\hline $\mathrm{Ni}$ & 50 & 40 & 10 & 19 & 28.5 & 33.7 \\
\hline $\mathrm{Zn}$ & 250 & 100 & 30 & 25 & 37 & 25.8 \\
\hline $\mathrm{Cu}$ & 100 & 35 & 100 & 60 & 63.8 & 59.8 \\
\hline $\mathrm{Cd}$ & 0.6 & 0.2 & 0.3 & - & 0.413 & 0.62 \\
\hline $\mathrm{Pb}$ & 300 & 35 & 40 & 19 & 20.4 & 29.2 \\
\hline
\end{tabular}
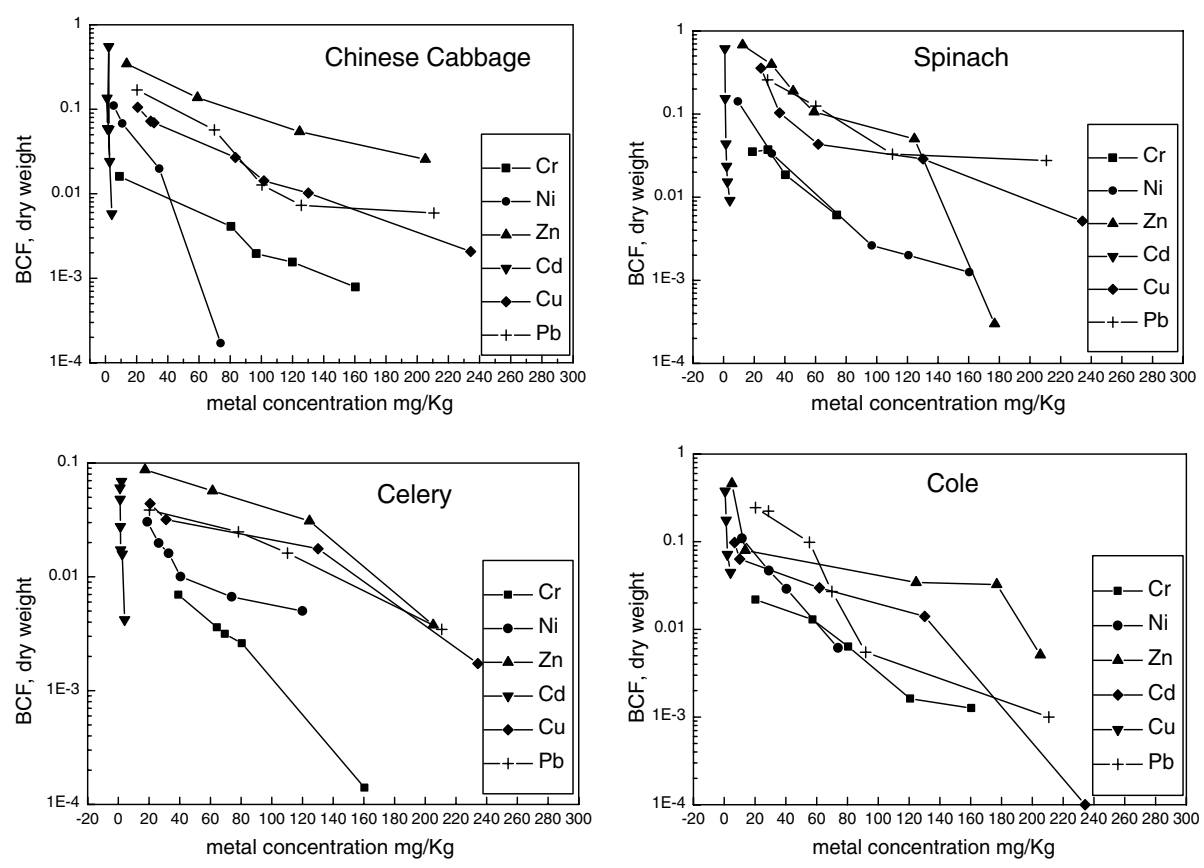

Fig. 1. BCF values for heavy metals in experimental soils.

paper showed good qualities. And if plants with good qualities were selected from contaminated soils, the metal content of plants would be higher than that selected from clean soils. Good qualities of plants concealed the fact of contamination and then induced the harmful effect to human health.

\subsection{Single extraction methods for prediction of the phytoavailablility of heavy elements in soils to vegetables}

Currently, the phytoavailability of metals in soils to plants is generally determined by correlating the concentrations of metals in plants with that in various soil fractions determined by single and/or sequential extraction procedures. The phytoavailability varies with plant species and properties of given soils. In this paper, we use single regression and multiple regression analyses to compare the suitability of various extraction methods for phytoavailability of heavy metals under the field conditions. The positive correlation suggests that the extraction procedure is suitable for the evaluation of metal accumulation in plants. However, the negative correlation means that this extraction method cannot illustrate the accumulation of metals to vegetables.

Table 4 lists the range of metal concentrations in the different extractable fractions and Tables 5 and 6 display the correlation coefficients obtained by single regression analysis. The metal concentrations with four extractants were ranged from 3.42 to $815,1.51-6965,0.732-24473$, $0.688-7863,0.246-685,1.99-53370.203-4649 \mathrm{ng} / \mathrm{g}$ for $\mathrm{Cr}, \mathrm{Ni}, \mathrm{Zn}, \mathrm{Cu}, \mathrm{Cd}, \mathrm{Pb}$ and REEs, respectively. The $\mathrm{CH}_{3}$ $\mathrm{COOH}$ - and DTPA-extractable metals are higher than 
Table 4

The extractable metal contents of different extractants (ng/g, dry mass)

\begin{tabular}{lllll}
\hline & $\mathrm{CaCl}_{2}$ & $\mathrm{DTPA}$ & $\mathrm{CH}_{3} \mathrm{COOH}$ & $\mathrm{H}_{2} \mathrm{O}$ \\
\hline $\mathrm{Cr}$ & $20.4-65.5$ & $37.2-244$ & $154-815$ & $3.42-91.5$ \\
$\mathrm{Ni}$ & $51.1-406$ & $8.45-175$ & $19.9-6965$ & $1.51-197$ \\
$\mathrm{Zn}$ & $5.82-2595$ & $39.7-16171$ & $59.8-24473$ & $0.732-335$ \\
$\mathrm{Cu}$ & $32.2-4401$ & $253-7863$ & $152-2817$ & $0.688-299$ \\
$\mathrm{Cd}$ & $1.69-182$ & $7.46-436$ & $6.25-685$ & $0.246-52.6$ \\
$\mathrm{~Pb}$ & $40.5-5322$ & $601-5337$ & $112-3056$ & $1.99-332$ \\
$\mathrm{La}$ & $6.62-3017$ & $47.2-1805$ & $115-605$ & $0.373-59.4$ \\
$\mathrm{Ce}$ & $10.4-3890$ & $79.2-2516$ & $120-87.6$ & $1.27-193$ \\
$\mathrm{Pr}$ & $1.80-650$ & $11.9-1201$ & $16.2-132$ & $0.346-14.5$ \\
$\mathrm{Nd}$ & $5.43-2092$ & $36.9-4649$ & $76-1469$ & $0.203-41.5$ \\
\hline
\end{tabular}

Table 5

Correlation coefficients between the extracted metal concentrations in 14 soils and metal concentrations in roots of four vegetables

\begin{tabular}{|c|c|c|c|c|c|c|c|c|}
\hline & \multicolumn{2}{|c|}{ Chinese cabbage } & \multicolumn{2}{|l|}{ Spinach } & \multicolumn{2}{|l|}{ Celery } & \multicolumn{2}{|l|}{ Cole } \\
\hline & $\mathrm{CaCl}_{2}$ & DTPA & $\mathrm{CaCl}_{2}$ & DTPA & $\overline{\mathrm{CaCl}_{2}}$ & DTPA & $\overline{\mathrm{CaCl}_{2}}$ & DTPA \\
\hline $\mathrm{Cr}$ & $0.5411^{* *}$ & $0.7105^{* *}$ & 0.4119 & $0.7238^{* *}$ & -0.2671 & $0.4925^{*}$ & 0.2187 & $0.5083^{*}$ \\
\hline $\mathrm{Ni}$ & 0.01226 & 0.09823 & 0.0793 & $-0.4396^{*}$ & -0.1368 & 0.00304 & -0.04146 & 0.1005 \\
\hline $\mathrm{Zn}$ & $0.6352^{* *}$ & 0.3623 & 0.3328 & 0.2566 & $0.5859^{* *}$ & 0.3687 & $0.8511^{* *}$ & 0.3469 \\
\hline $\mathrm{Cu}$ & 0.1415 & -0.06819 & -0.00921 & -0.1434 & -0.1493 & 0.1557 & 0.2251 & 0.01306 \\
\hline $\mathrm{Cd}$ & $0.6979^{* *}$ & $0.5206^{* *}$ & $0.4716^{*}$ & $0.4625^{*}$ & $0.7215^{* *}$ & $0.6862^{* *}$ & $0.4268^{*}$ & $0.5518^{* *}$ \\
\hline $\mathrm{Pb}$ & $0.5537^{* *}$ & $0.6914^{* *}$ & $0.5492^{* *}$ & $0.6507^{* *}$ & $0.5519^{* *}$ & 0.09117 & $0.5765^{* *}$ & $0.5549^{* *}$ \\
\hline $\mathrm{La}$ & $0.5185^{* *}$ & $0.4953^{* *}$ & $0.6217^{* *}$ & $0.4845^{* *}$ & -0.1477 & -0.1727 & $0.8837^{* *}$ & $0.5838^{* *}$ \\
\hline $\mathrm{Ce}$ & $0.6684^{* *}$ & $0.5202^{* *}$ & $0.5649^{* *}$ & $0.4394^{*}$ & -0.1288 & 0.2525 & $0.7116^{* *}$ & $0.5518^{* *}$ \\
\hline $\operatorname{Pr}$ & $0.5502^{* *}$ & 0.2708 & $0.4799^{* *}$ & $0.5095^{* *}$ & -0.1493 & -0.05887 & $0.9542^{* *}$ & $0.5579^{* *}$ \\
\hline $\mathrm{Nd}$ & $0.5233^{* *}$ & $0.5594^{* *}$ & $0.5079^{* *}$ & $0.5012^{* *}$ & -0.1139 & -0.04392 & $0.6102^{* *}$ & $0.6796^{* *}$ \\
\hline
\end{tabular}

${ }^{*}$ and ${ }^{* *}$ significance at $10 \%$ and $5 \%$ level, respectively.

Table 6

Correlation coefficients between the extracted metal concentrations in 14 soils and metal concentrations in the shoots of four vegetables

\begin{tabular}{|c|c|c|c|c|c|c|c|c|}
\hline & \multicolumn{2}{|c|}{ Chinese cabbage } & \multicolumn{2}{|l|}{ Spinach } & \multicolumn{2}{|l|}{ Celery } & \multicolumn{2}{|l|}{ Cole } \\
\hline & $\mathrm{CaCl}_{2}$ & DTPA & $\mathrm{CaCl}_{2}$ & DTPA & $\mathrm{CaCl}_{2}$ & DTPA & $\mathrm{CaCl}_{2}$ & DTPA \\
\hline $\mathrm{Cr}$ & 0.3852 & $-0.5768^{*}$ & $0.4104^{*}$ & $-0.7417^{* *}$ & $0.4993^{* *}$ & $-0.6529^{* *}$ & 0.2601 & -0.5465 \\
\hline $\mathrm{Ni}$ & 0.2945 & 0.05408 & 0.2587 & $-0.5653^{* *}$ & 0.3786 & -0.4406 & 0.4527 & -0.3258 \\
\hline $\mathrm{Zn}$ & 0.202 & -0.3939 & 0.3032 & 0.01291 & $0.5806^{* *}$ & -0.1644 & 0.3936 & -0.04584 \\
\hline $\mathrm{Cu}$ & 0.2355 & -0.2864 & $0.8233^{* *}$ & -0.0444 & $0.8995^{* *}$ & -0.07706 & 0.106 & -0.3597 \\
\hline $\mathrm{Cd}$ & 0.2236 & 0.04744 & -0.2217 & 0.1244 & -0.34715 & -0.05717 & -0.1537 & -0.2463 \\
\hline $\mathrm{Pb}$ & $0.8045^{* *}$ & $0.7204^{* *}$ & $0.4489^{*}$ & $0.4813^{*}$ & $0.6397^{* *}$ & -0.3883 & $0.6449^{* *}$ & $0.6585^{*}$ \\
\hline $\mathrm{La}$ & 0.0542 & 0.2434 & $0.7473^{* *}$ & $0.4944^{* *}$ & $0.5999^{* *}$ & 0.3472 & $0.4665^{*}$ & $0.8046^{* *}$ \\
\hline $\mathrm{Ce}$ & 0.2256 & 0.1032 & $0.7177^{* *}$ & $0.5659^{* *}$ & 0.2699 & -0.05079 & $0.4988^{* *}$ & $0.7921^{* *}$ \\
\hline $\operatorname{Pr}$ & 0.2434 & 0.1258 & $0.6343^{* *}$ & $0.4422^{*}$ & $0.6715^{* *}$ & $0.5726^{* *}$ & $0.4529^{*}$ & $0.7748^{* *}$ \\
\hline $\mathrm{Nd}$ & 0.1635 & 0.1528 & $0.6492^{* *}$ & $0.4779^{*}$ & 0.4051 & 0.3373 & 0.4432 & $0.7373^{* *}$ \\
\hline
\end{tabular}

${ }^{*}$ and ${ }^{* *}$ significance at $10 \%$ and $5 \%$ level, respectively.

other that extracted by other extractants. Water extractable metals were the lowest one. As can be seen from these tables, the correlation coefficients of roots were prevalently better than that of shoots, suggesting that vegetable roots were a good indicator of metal phytoavailability. In calcareous soils high soil $\mathrm{pH}$ was likely to promote the release of more metals from soils. The released metals were easily accumulated in plant roots (Chaignon et al., 2003). This may also be the possible reason to interpret why roots have good correlation coefficients. From these correlations, we found that the root metal concentrations increased with increasing metal concentrations in the extractable fractions of soils. Besides $\mathrm{Cr}, \mathrm{Zn}, \mathrm{Cd}$ and $\mathrm{Pb}$, the concentrations of REEs always revealed better correlations with plant roots (for spinach, good correlations were 
also found in its shoots for REEs). This discrepancy existed among heavy metals and rare earth elements may be caused by the different elemental speciation in soils. A widely accepted opinion is that the metal uptake by roots occurs from soil pore water. For some metals, such as $\mathrm{Zn}$ and $\mathrm{Cd}$, they are primarily as soluble or exchangeable, readily bioavailable forms (Lasat, 2002). These bioavailable forms can be easily taken by plant roots, which explained the reason for good correlation coefficients. However, it should be pointed out that correlation between concentrations in plant roots and extracted fractions was poor for $\mathrm{Cu}$.

$\mathrm{CaCl}_{2}$ is the primary component of soil background electrolytes. The exchangeable cations may be displaced by the basic cations commonly present in extraction solutions $\left(\mathrm{Ca}^{2+}\right)$. Heavy metals and REEs, which are originally absorbed by soils will be competed by calcium ions and be replaced from the binding sites. Compared to other methods employed in this paper, $0.01 \mathrm{M} \mathrm{CaCl}_{2}$ seems to be the best one based on the good correlations, which suggests that the plants are able to take up the great mass of the metals extracted by $\mathrm{CaCl}_{2}$. DTPA, and $\mathrm{CH}_{3} \mathrm{COOH}$ are all chelating reagents. DTPA extractable metals were correlated with metal concentrations in plant roots well. The reason why DTPA shows a better correlation may lie in the fact that the DTPA extractant contains a high concentration of $\mathrm{CaCl}_{2}$, of which $\mathrm{Ca}^{2+}$ may exchange rapidly with bivalent cations, especially $\mathrm{Cd}^{2+}$ and $\mathrm{Zn}^{2+}$ from soils. DTPA contains triethanolamine (TEA), which is protonated at $\mathrm{pH} 7.3$ and could exchange $\mathrm{H}^{+}$with cations from the exchange sites as suggested by Lindsay and Norvel (1978).

Using organic acids to extract bioavailable metals from soils has been accepted because organic acids can dissolve the particulate-bound metals into soil solution and are exudates of plant roots (Cieslinske et al., 1998). From our investigation, $\mathrm{CH}_{3} \mathrm{COOH}$ showed good relations only for $\mathrm{Cd}$. Although acetic acid comprise the largest component of total organic acids in rhizosphere soil of plants (Baziramakenga et al., 1995), formic acid, citric acid and malic acids are frequently found to be the other major components of total organic acids and have relatively abundant concentrations (Jones et al., 1996). Of course, the ratio of these organic acids varies from soil to soil and from plant to plant as well. Therefore, the soil fraction extracted only by acetic acid provides no insight into the real amount of metals transferred from soil to plant.

It should be pointed out that water-extractable metals were not at all correlated with the concentration of metals in vegetables except for Chinese cabbage. The correlation coefficients between the extracted metal concentrations by $\mathrm{CH}_{3} \mathrm{COOH}$ and water are not included in Tables 4 and 5.

Lead is strongly bound with soil particles, which renders a significant soil $\mathrm{Pb}$ fraction insoluble, display- ing a low phytoavailability. However, $\mathrm{Pb}$ contents in plant shoots indicated remarkable positive correlations with that of $\mathrm{CaCl}_{2}$-extractable $\mathrm{Pb}$ (i.e., $r=0.8045^{* *}$ for Chinese cabbage). Even water-extractable $\mathrm{Pb}$ shows a good correlation with $\mathrm{Pb}$ contents in plant shoots $(r=$ $0.6153^{* *}$ for Chinese cabbage) and roots $\left(r=0.7030^{* *}\right.$ for Chinese cabbage). These good correlations demonstrated that the exchangeable $\mathrm{Pb}$, water soluble $\mathrm{Pb}$ were the bioavailable to vegetables. One source of $\mathrm{Pb}$ contamination in soil was probably from air pollution. Although the use of gasoline containing $\mathrm{Pb}$ has been forbidden for several years, the sedimentation rate of $\mathrm{Pb}$ was reported to be very slow from the surface soil to deep-seated soil (Lasat, 2002). Studies have showed that the availability of metals is considerably reduced by aging, due to the formation of strong bonds to soil particles and/or incorporation into resistant secondary minerals of low phytoavailability (e.g., iron oxides). As for the young flue-dust contaminated soils, $\mathrm{Pb}$ existed in the surface soil was loosely associated with soil particles and was easily dissolved by soil pore water or exchanged by $\mathrm{Ca}^{2+}$. This is the reason why $\mathrm{Pb}$ contents in plant shoots shows positive relations with that of $\mathrm{CaCl}_{2}$ - and water-extractable $\mathrm{Pb}$ in soil solution. As for the different plants, the celery behaved the worst correlation coefficients for REEs, suggesting the complexity of plant uptake of trace elements and the diversity of the microcosmic process of plant rhizosphere.

\subsection{Relationship between soil properties and extractable metals of $\mathrm{CaCl}_{2}$ and DTPA}

Table 7 demonstrates the relationships between the metal contents in extractable fractions and soil properties (OM, pH, CEC). As can be seen from this table that $\mathrm{CaCl}_{2}$ and DTPA methods showed different correlations with soil properties. This may due to the different extraction mechanisms. $\mathrm{Ca}^{2+}$ can exchange and then replace most of divalent metal ions from their binding sites of soil particles. DTPA, a strong chelator for metals, can even extract metals from other metalorganic complexes (Hammer and Keller, 2002). This is the reason why the concentrations of many heavy metals in their DTPA extractable fractions can exhibit positive correlations with the soil organic matter contents, whereas $\mathrm{CaCl}_{2}$ cannot.

Except for $\mathrm{Ni}$ and $\mathrm{Cd}$, extractable metals exerted a positive linear correlation with soil $\mathrm{pH}$ when $\mathrm{CaCl}_{2}$ was used as extractant. This result was supported by the viewpoints of Chaignon et al. (2003). Chaignon et al. (2003) suggested that the higher ambient $\mathrm{pH}$ of calcareous soils was likely to promote the release of more metals from soils, which were easily taken by plant root cells. However, for DTPA being buffered at $\mathrm{pH}$ 7.3, only copper exhibited positive $\mathrm{pH}$-dependency. 
Table 7

Single linear correlation coefficients between extractable metal concentrations and soil properties

\begin{tabular}{|c|c|c|c|c|c|c|}
\hline & \multicolumn{2}{|l|}{ OM } & \multicolumn{2}{|l|}{$\mathrm{pH}$} & \multicolumn{2}{|l|}{ CEC } \\
\hline & $\mathrm{CaCl}_{2}$ & DTPA & $\mathrm{CaCl}_{2}$ & DTPA & $\mathrm{CaCl}_{2}$ & DTPA \\
\hline $\mathrm{Cr}$ & 0.238 & $0.403^{*}$ & $0.493^{* *}$ & -0.332 & $-0.677^{* *}$ & $0.663^{* *}$ \\
\hline $\mathrm{Ni}$ & 0.279 & $0.504^{* *}$ & 0.237 & 0.055 & $-0.463^{* *}$ & $0.554^{* *}$ \\
\hline $\mathrm{Zn}$ & 0.234 & $0.442^{* *}$ & $0.410^{*}$ & 0.364 & -0.176 & 0.305 \\
\hline $\mathrm{Cu}$ & -0.167 & $0.503^{* *}$ & $0.558^{*}$ & $0.580^{* *}$ & $-0.619^{* *}$ & 0.247 \\
\hline $\mathrm{Cd}$ & 0.295 & 0.313 & -0.262 & 0.115 & $0.501^{* *}$ & 0.309 \\
\hline $\mathrm{Pb}$ & -0.125 & 0.162 & $0.550^{* *}$ & $0.668^{* *}$ & $-0.6591^{* *}$ & -0.0994 \\
\hline $\mathrm{La}$ & -0.184 & $-0.431^{* *}$ & $0.571^{* *}$ & 0.134 & $-0.651^{* *}$ & $-0.741^{* *}$ \\
\hline $\mathrm{Ce}$ & -0.161 & $-0.496^{* *}$ & $0.578^{* *}$ & -0.000747 & $-0.663^{* *}$ & $-0.423^{*}$ \\
\hline $\operatorname{Pr}$ & -0.195 & -0.268 & $0.493^{* *}$ & 0.199 & $-0.691^{* *}$ & $-0.599^{* *}$ \\
\hline $\mathrm{Nd}$ & -0.188 & -0.201 & $0.480^{* *}$ & 0.242 & $-0.699^{* *}$ & $-0.597^{* *}$ \\
\hline
\end{tabular}

${ }^{*}$ and ${ }^{* *}$ significance at $10 \%$ and $5 \%$ level, respectively.

The influence of CEC on the extraction using different extractants was discussed. The REEs concentrations in the extractable fractions of both $\mathrm{CaCl}_{2}$ and DTPA were negatively correlated with $\mathrm{CEC}$, demonstrating that REEs were more easily sequestered than other metals under higher CEC conditions. Stewart et al. (2003) have testified that the higher soil CEC generally has higher content of clay and organic matters, and hence show strong ability on the sequestration of metals. Because of the higher ion charge (trivalent of La and quadrivalent $\mathrm{Ce}$, etc.) of REEs, the interactions occur between REEs and binding sites, thus retarding the release of REEs from the soil particles. Additionally, with the increase of $\mathrm{CEC}, \mathrm{Cr}$ and $\mathrm{Ni}$ concentrations in the extractable fractions of DTPA increased too. Since the mechanism of $\mathrm{Cr}$ and $\mathrm{Ni}$ retardation on clay minerals (clay content of soils was the first most important determinant of the CEC value of soils) was primarily weak electrostatic-bond interaction, these bonds were easily broken under the extraction of a strong chelator of DPTA, allowing $\mathrm{Cr}$ and $\mathrm{Ni}$ desorbed from the soil and released into solution (Stewart et al., 2003).
3.6. Relationship between soil properties and the phytoavailability of metals to vegetables

The correlations between the metal concentrations in plant roots and soil properties are listed in Table 8. As for the effect of OM, only the phytoavailability of $\mathrm{Cr}$ and $\mathrm{Cu}$ expressed positive correlations with the organic matter contents of soils. Some literatures held the opinions that the metals combined with organic matters were difficult to be taken by plants. However, the opposite view was that the organic-binding metals can be easily decomposed by anaerobic metal-reducing bacteria and then be absorbed by plants. Soil $\mathrm{Cu}$ and $\mathrm{Cr}$ uptake by plants is an interesting area, and literatures have illustrated that $\mathrm{Cu}$ always combined with organic ligands of soils. The $\mathrm{Cu}$-fulvic acid, $\mathrm{Cu}$-humic acid complexes in soil solution seemed to be the forms easily taken by plants (Krishnamurti and Naidu, 2002). Stewart et al. (2003) also suggested that the concentration of $\mathrm{Cr}$ was higher in the organic-bound fractions than in the soluble and exchangeable fractions. Hansel et al. (2003) have investigated the microbial decomposition of $\mathrm{Cr}$ -

Table 8

Single linear correlation coefficients between metal concentrations of the roots of vegetables and soil properties

\begin{tabular}{|c|c|c|c|c|c|c|c|c|c|c|c|c|}
\hline & \multicolumn{4}{|l|}{$\mathrm{OM}$} & \multicolumn{4}{|l|}{$\mathrm{pH}$} & \multicolumn{4}{|l|}{ CEC } \\
\hline & $\begin{array}{l}\text { Chinese } \\
\text { cabbage }\end{array}$ & Spinach & Celery & Cole & $\begin{array}{l}\text { Chinese } \\
\text { cabbage }\end{array}$ & Spinach & Celery & Cole & $\begin{array}{l}\text { Chinese } \\
\text { cabbage }\end{array}$ & Spinach & Celery & Cole \\
\hline $\mathrm{Cr}$ & $0.447^{*}$ & 0.116 & $0.430^{*}$ & $0.586^{* *}$ & -0.168 & $-0.361^{*}$ & 0.179 & -0.193 & $0.538^{* *}$ & $0.443^{* *}$ & $0.560^{* *}$ & -0.0229 \\
\hline $\mathrm{Ni}$ & 0.0435 & -0.299 & 0.0868 & 0.253 & $-0.387^{*}$ & -0.261 & 0.175 & -0.202 & -0.217 & -0.264 & $0.576^{* *}$ & -0.293 \\
\hline $\mathrm{Zn}$ & 0.218 & 0.216 & 0.353 & 0.384 & 0.251 & -0.322 & 0.189 & 0.195 & 0.0818 & 0.0956 & 0.339 & -0.303 \\
\hline $\mathrm{Cu}$ & 0.203 & $0.355^{*}$ & $0.623^{* *}$ & $0.421^{*}$ & -0.00074 & 0.187 & $-0.477^{*}$ & 0.35 & -0.128 & 0.126 & $-0.490^{* *}$ & $-0.512^{* *}$ \\
\hline $\mathrm{Cd}$ & 0.309 & 0.153 & -0.0393 & 0.343 & $-0.422^{*}$ & -0.23 & 0.272 & $-0.386^{*}$ & 0.118 & 0.139 & -0.0847 & -0.0931 \\
\hline $\mathrm{Pb}$ & -0.0722 & -0.191 & 0.356 & 0.181 & $0.471^{*}$ & $0.505^{* *}$ & $0.547^{* *}$ & $0.415^{*}$ & $-0.614^{* *}$ & $-0.406^{*}$ & $-0.614^{* *}$ & $-0.527^{* *}$ \\
\hline $\mathrm{La}$ & -0.0282 & -0.122 & -0.0598 & -0.173 & 0.29 & 0.325 & 0.307 & $0.516^{* *}$ & $-0.466^{*}$ & $-0.384^{*}$ & -0.363 & $-0.631^{* *}$ \\
\hline $\mathrm{Ce}$ & 0.00276 & -0.11 & -0.0475 & -0.00914 & 0.214 & 0.358 & 0.368 & -0.0653 & $-0.475^{*}$ & -0.365 & $-0.384^{*}$ & -0.114 \\
\hline $\operatorname{Pr}$ & 0.0761 & -0.0984 & -0.0881 & -0.223 & 0.125 & 0.341 & 0.285 & $0.527^{* *}$ & $-0.395^{*}$ & $-0.368^{*}$ & $-0.361^{*}$ & $-0.672^{* *}$ \\
\hline $\mathrm{Nd}$ & 0.0631 & -0.0986 & -0.173 & -0.271 & 0.162 & $0.412^{*}$ & 0.223 & $0.523^{* *}$ & $-0.447^{*}$ & -0.364 & $-0.395^{*}$ & $-0.606^{* *}$ \\
\hline
\end{tabular}

${ }^{*}$ and ${ }^{* *}$ significance at $10 \%$ and $5 \%$ level, respectively. 
natural organic matter fractions. All these results supported the conclusion that higher soil OM enhanced the phytoavailability of $\mathrm{Cr}$ and $\mathrm{Cu}$.

Considering the effect of soil $\mathrm{pH}$ on the phytoavailability of metals to vegetables, we found that only $\mathrm{Pb}$ uptake showed a positive $\mathrm{pH}$-dependency. This positive correlation suggested that high soil $\mathrm{pH}$ could increase the availability of these metals to plants. Generally, with decreasing $\mathrm{pH}$, pronounced increase in release rate of $\mathrm{Pb}$ was observed. The lower soil $\mathrm{pH}$, the higher $\mathrm{Pb}^{2+}$ concentrations can be found in soil solution (Badawy et al., 2002; Sukreeyapongse et al., 2002). However, among these calcareous soils $\mathrm{Pb}$ in soils was probably from air pollution and the $\mathrm{Pb}^{2+}$ was loosely bond with soil particles. In that case, $\mathrm{Pb}^{2+}$ seems to be easily bound to root cell walls. Therefore, it was possible that a large proportion of $\mathrm{Pb}$ in plant roots were adsorbed by root cell walls due to the high ambient $\mathrm{pH}$ (Chaignon et al., 2003). Therefore, this reversed the positive dependence of soil $\mathrm{pH}$ on $\mathrm{Pb}$ uptake by plants, which was observed in this paper. As observed by other authors that $\mathrm{Ni}, \mathrm{Cd}$, $\mathrm{Cu}$ and $\mathrm{Cr}$ showed negative correlations between their uptake by plants and soil $\mathrm{pH}$ (Krishnamurti and Naidu, 2002, Stewart et al., 2003).

The uptake of $\mathrm{Pb}$ and REEs by different vegetables seems to be increased with the decrease of the cation exchange capacity of soils, which is evidenced by the negative correlation coefficients. This result was consistent with the results obtained for the relationship between metals in soil extractable fractions and soil CEC. It seems that metals in clay materials with higher CEC are not available to plants.

From these results, we concluded that the soil properties could remarkably influence the phytoavailability of trace elements. However, soil properties display more complicated effects on the phytoavailabilities of metals to plants. So it was very important to investigate the combined effects of these factors on the phytoavailability of metals to plants, especially under the real-field conditions.

\subsection{Multiple regression analysis model for evaluation of phytoavailability}

Principally, the single extraction and sequential extraction methods were based on the assumption that there was a relationship between the extractable fraction of metals and the phytoavailability of metals to plants, and a good correlation reflected that fraction of metals in soils was available to plants. However, it was not always true that a statistically valid correlation of soil-toplant system could provide insight into the mechanisms of phytoavailability. Because the chemical, biological and physical mechanisms governed the translocation of metals from soils; therefore, high variability of phytoavailability was always observed in the literature. Con- sidering this situation, we integrated soil $\mathrm{pH}, \mathrm{OM}, \mathrm{CEC}$, total metal concentrations of soils and extractable metal concentrations in soil solutions together to simulate the combined effects of rhizosphere microenvironment, and an empirical model was derived to express the relationships between metal phytoavailability and properties of rhizosphere.

$$
\begin{aligned}
\log \left[M_{\text {root }}\right]= & a+b \log \left[M_{\text {soil }}\right]+c \mathrm{OM}+d \mathrm{pH} \\
& +e \mathrm{CEC}+f \log \left[M_{\text {extra }}\right]
\end{aligned}
$$

where $\left[M_{\text {root }}\right]$ and $\left[M_{\text {soil }}\right]$ were the total metal concentrations in plant roots and in soils, respectively. $\left[M_{\text {extra }}\right]$ was the metal concentration in the extractable soil fractions. $a-f$ were coefficients determined with statistical regression. According to this model, a step-wise multiple regression analysis was performed and the correlations were largely improved (Table 9). Besides this improvement, the model also passed the normality $t$-test, suggesting that the data was normally distributed around the regression line and that the variance presented in the dependent variable was constant. For the multiple linear regressions, the $r^{2}$ values can be used to explain the variation of the dependents. From this table we can see that the $r^{2}$ values were above 0.700 (extracted by $\mathrm{CaCl}_{2}$ ), which means that more than $70 \%$ of variation in root uptake of trace elements can be described by soil $\mathrm{pH}, \mathrm{CEC}, \mathrm{OM}$ and metal concentrations. Among the extraction methods studied, $\mathrm{CaCl}_{2}$ and DTPA gave better correlation coefficients. The $r^{2}$ values of these two methods were larger than that of other methods and the significance level was also satisfied. The multiple regression model was statistically rigorous at the $95 \%$ confidence level since $P$ values for the independent variables were all $<0.05$. Combined with the results obtained by the linear regression (Tables 5-7 and 9) one could conclude that under the real field conditions, $\mathrm{CaCl}_{2}$ and DTPA methods were suitable for predicting the phytoavailability of trace elements in soils to vegetables. For the health risk assessments, the concentrations of trace elements in vegetables could be predicted by means of the equation.

The coefficients of each influence factor can be used to evaluate the influence ability of these factors. Table 10 lists the model parameters of different influence factors. For example, the recommended model suggested that Cr phytoavailability of celery was enhanced by higher soil metal contents, higher organic matter contents, higher CEC and lower soil $\mathrm{pH}$ (positive coefficients showed positive effect and vice versa). As the exchangeable metal fractions are assumed to be easily absorbed fractions to plants, the great contribution of total metal concentrations in soils indicated that some soil fractions of metals could also be absorbed indirectly through the decomposition of metal-organic matter complexes by microorganisms. According to the present model a 
Table 9

Correlation coefficients obtained by multiple regression

\begin{tabular}{|c|c|c|c|c|c|}
\hline & & $\mathrm{CaCl}_{2}$ & DTPA & $\mathrm{CH}_{3} \mathrm{COOH}$ & $\mathrm{H}_{2} \mathrm{O}$ \\
\hline & & $r^{2}$ value & & & \\
\hline \multirow[t]{3}{*}{ Chinese cabbage } & $\mathrm{Cr}$ & $0.736^{* *}$ & $0.807^{* *}$ & $0.785^{* *}$ & $0.748^{*}$ \\
\hline & $\mathrm{Zn}$ & $0.689^{*}$ & 0.478 & 0.218 & 0.392 \\
\hline & $\mathrm{Pb}$ & $0.717^{* *}$ & $0.747^{* *}$ & $0.798^{* *}$ & 0.697 \\
\hline Spinach & $\mathrm{Cr}$ & $0.885^{* *}$ & $0.819^{* *}$ & $0.819^{* *}$ & $0.801^{* *}$ \\
\hline \multirow[t]{9}{*}{ Celery } & $\mathrm{Cr}$ & $0.849^{* *}$ & $0.941^{* *}$ & $0.956^{* *}$ & $0.881^{* *}$ \\
\hline & $\mathrm{Ni}$ & $0.954^{* *}$ & $0.861^{* *}$ & $0.875^{* *}$ & $0.867^{* *}$ \\
\hline & $\mathrm{Zn}$ & $0.834^{* *}$ & $0.864^{* *}$ & $0.864^{* *}$ & $0.845^{* *}$ \\
\hline & $\mathrm{Cu}$ & $0.754^{* *}$ & $0.717^{*}$ & 0.654 & 0.687 \\
\hline & $\mathrm{Cd}$ & $0.898^{* *}$ & $0.612^{*}$ & 0.541 & 0.439 \\
\hline & $\mathrm{La}$ & $0.867^{* *}$ & $0.773^{*}$ & 0.666 & 0.661 \\
\hline & $\mathrm{Ce}$ & $0.757^{* *}$ & $0.893^{* *}$ & $0.777^{*}$ & $0.745^{*}$ \\
\hline & $\operatorname{Pr}$ & $0.887^{* *}$ & $0.765^{*}$ & 0.589 & 0.629 \\
\hline & $\mathrm{Nd}$ & $0.874^{* *}$ & $0.754^{*}$ & 0.612 & 0.647 \\
\hline \multirow[t]{8}{*}{ Cole } & $\mathrm{Cr}$ & $0.769^{* *}$ & $0.781^{*}$ & $0.772^{*}$ & $0.742^{*}$ \\
\hline & $\mathrm{Zn}$ & $0.896^{* *}$ & $0.838^{* *}$ & $0.836^{* *}$ & 0.664 \\
\hline & $\mathrm{Cu}$ & $0.741^{* *}$ & $0.791^{*}$ & $0.834^{* *}$ & $0.748^{*}$ \\
\hline & $\mathrm{Cd}$ & $0.749^{* *}$ & 0.588 & 0.586 & 0.573 \\
\hline & $\mathrm{Pb}$ & $0.825^{* *}$ & $0.692^{*}$ & 0.496 & 0.421 \\
\hline & $\mathrm{La}$ & $0.774^{* *}$ & 0.498 & 0.497 & 0.519 \\
\hline & $\operatorname{Pr}$ & $0.802^{* *}$ & $0.768^{*}$ & $0.739^{*}$ & $0.746^{*}$ \\
\hline & $\mathrm{Nd}$ & $0.806^{* *}$ & $0.727^{*}$ & 0.659 & 0.629 \\
\hline
\end{tabular}

${ }^{*}$ and ${ }^{* *}$ significance at $10 \%$ and $5 \%$ level, respectively.

good fitting was achieved if total metal concentrations in soils were integrated. However, Cd uptake by celery was an exception even total soil metal concentrations and organic matter contents were not included in the model fitting, since the other three independent can describe approximately $90 \%$ of the variability of Cd uptake. Among the six parameters involved in this model, intercorrelated reaction between them are obvious, e.g., the metal concentration in the extractable fraction correlated with soil total metal concentration; concentration in the extractable fraction correlated with $\mathrm{OM}, \mathrm{pH}$ and $\mathrm{CEC}$ etc. However, the coefficients obtained in this model can regulate these cross-effects and make the better model fitting. For example, as for celery, although there was correlation between the total $\mathrm{Cr}$ concentration of soils and the extractable $\mathrm{Cr}$ concentrations, both these two influences gave the positive effect on the phytoavailability of $\mathrm{Cr}$. The total $\mathrm{Cr}$ concentration of soils was the leading influence factor on the phytoavailability of $\mathrm{Cr}$ to celery (the coefficient $b$ was positive and greater than other parameters). However, this influence was not sufficient and need the extractable $\mathrm{Cr}$ concentration to complement (the coefficient $f$ is also positive). As mentioned above, as for celery, only the extractable Cd significantly contributed to the phytoavailability of $\mathrm{Cd}(f=3.12)$ and the total $\mathrm{Cd}$ metal concentration was not a main variable.
In Tables 8 and 9 there were different correlation coefficients for different plant species. As for celery, the total metal concentration influenced phytoavailability dominantly (great $b$ values were observed, except for Cd). Nevertheless, the extractable metal concentration was the major contributor to the phytoavailability of metals to cole (except for $\mathrm{Pb}$ and $\mathrm{Cd}$, great $f$ values were observed).

It was interesting to note that for celery and cole, this model proved to be suitable for 9 metals $(\mathrm{Cr}, \mathrm{Ni}, \mathrm{Zn}, \mathrm{Cu}$, $\mathrm{Cd}, \mathrm{La}, \mathrm{Ce}, \mathrm{Pr}$ and $\mathrm{Nd}$ ). Nevertheless, as for spinach and Chinese cabbage, only 1 and 3 metals showed strongly correlations. Celery and cole, which had thriving rootlets and root hairs, exhibited excellent positive correlations if $\mathrm{CaCl}_{2}$ and DTPA extraction methods were used. However, Chinese cabbage had straight roots and a few adnascent roots. Probably due to this fact only three elements displayed the positive relations. The spinach root is stout (no lateral root attached), which grows straight downward from the stem. This is the possible reason for only $\mathrm{Cr}$ showed positive relations. The more plant roots were thriving, the better correlations were obtained.

Based on the above study one could draw a conclusion that, on the one hand, soil properties affect the phytoavailability of metals in soils, such influences should be considered in the evaluation of phytoavailability. On the other hand, plant roots governed the 
Table 10

Parameters for multiple regression analysis

\begin{tabular}{|c|c|c|c|c|c|c|c|}
\hline & & $a$ & $b$ & $c$ & $d$ & $e$ & $f$ \\
\hline \multirow[t]{9}{*}{ Celery } & $\mathrm{Cr}$ & 4.64 & 0.849 & 0.116 & -0.205 & 0.00556 & -1.38 \\
\hline & $\mathrm{Ni}$ & -1.12 & 1.11 & 0.0137 & 0.182 & 0.00647 & 0.514 \\
\hline & $\mathrm{Zn}$ & 3.85 & 0.564 & 0.0604 & -0.194 & 0.00289 & 0.145 \\
\hline & $\mathrm{Cu}$ & 1.72 & 0.152 & 0.0661 & 0.246 & 0.00163 & -0.00118 \\
\hline & $\mathrm{Cd}$ & -5.98 & - & - & 0.443 & -0.114 & 3.12 \\
\hline & $\mathrm{La}$ & -0.282 & 0.688 & 0.00671 & 0.313 & 0.00233 & -0.0514 \\
\hline & $\mathrm{Ce}$ & -0.693 & 0.739 & 0.00562 & 0.341 & 0.0308 & -0.0172 \\
\hline & $\operatorname{Pr}$ & -1.67 & 0.695 & -0.0294 & 0.516 & 0.00119 & -0.174 \\
\hline & $\mathrm{Nd}$ & -1.38 & 0.812 & -0.0384 & 0.481 & 0.00111 & -0.141 \\
\hline \multirow[t]{8}{*}{ Cole } & $\mathrm{Cr}$ & 3.98 & 0.191 & 0.0972 & 0.357 & 0.00269 & 0.711 \\
\hline & $\mathrm{Zn}$ & 3.42 & 0.141 & 0.0109 & -0.00252 & $-3.01 \times 10^{-4}$ & 0.283 \\
\hline & $\mathrm{Cu}$ & 2.19 & 0.253 & 0.0632 & -0.171 & -0.00313 & 0.0755 \\
\hline & $\mathrm{Cd}$ & 6.84 & 0.958 & 0.0993 & -0.554 & -0.00101 & -0.375 \\
\hline & $\mathrm{Pb}$ & 3.23 & 0.575 & 0.156 & -0.545 & 0.00422 & 0.952 \\
\hline & $\mathrm{La}$ & 5.32 & -0.146 & 0.0722 & -0.458 & $-7 \times 10^{-4}$ & 0.661 \\
\hline & $\operatorname{Pr}$ & 4.26 & -0.567 & 0.0328 & -0.153 & -0.0106 & 0.334 \\
\hline & $\mathrm{Nd}$ & -3.39 & -0.281 & -0.242 & 1.176 & -0.0118 & 0.411 \\
\hline
\end{tabular}

Note: $f$ is the parameter of $\mathrm{CaCl}_{2}$ extractable fraction.

metal availability, which was a forgotten area of study and was worthwhile research in the future. In a word, this model was more suitable for the plant, which had thriving rootlets and was applicable to predicting the phytoavailability of metals to the plants under the real field condition.

\section{Acknowledgement}

This work is supported by the National Natural Science Foundation of China (grant nos. 20237010, 20177030 and 40171086).

\section{References}

Badawy, S.H., Helal, M.I.D., Chaudri, M.A., Lawlor, K., McGrath, P., 2002. J. Environ. Qual. 31, 162-167.

Baziramakenga, R., Simard, R.R., Leroux, G.D., 1995. Determination of organic acids in soil extracts by ion chromatography. Soil Biol. Biochem. 27, 349-356.

Chaignon, V., Sanchez-Neira, I., Herrmann, P., Jaillard, B., Hinsinger, P., 2003. Copper bioavailability and extractability as related to chemical properties of contaminated soils from a vine-growing area. Environ. Pollut. 123, 229-238.

Chen, B., Shan, X.Q., Qian, J., 1996. Bioavailability index for quantitative evaluation of plant availability of extractable soil trace elements. Plant Soil 186, 275-283.

Cieslinske, G., Van Rees, K.C.J., Szmigielska, A.M., Krishnamurti, G.S.R., Huang, P.M., 1998. Low-molecularweight organic acids in rhizosphere soils of durum wheat and their effect on cadmium bioaccumulation. Plant Soil 203, 109-117.
Hansel, C.M., Wielinga, B.W., Fendorf, S.R., 2003. Structural and compositional evolution of $\mathrm{Cr} / \mathrm{Fe}$ solids after indirect chromate reduction by dissimilatory iron-reducing bacteria. Geochim. Cosmochim. Acta 67, 401-412.

Hammer, D., Keller, C., 2002. Changes in the rhizosphere of metal-accumulating plants evidenced by chemical extractants. J. Environ. Qual. 31, 1561-1569.

Houba, V.J.G., Lexmond, T.H.M., Novozamsky, I., Van der Lee, J.J., 1996. State of the art and future developments in soil analysis for bioavailability assessment. Sci. Total Environ. 178, 21-28.

Jones, D.L., Darrah, P.R., Kochian, L.V., 1996. Critical evaluation of organic acid mediated iron dissolution in the rhizosphere and its potential role in root iron uptake. Plant Soil 180, 57-66.

Kabata-Pendias, A., 1993. Behavioural properties of trace metals in soils. Appl. Geochem. 2, 3-9.

Krishnamurti, G.S.R., Naidu, R., 2002. Solid-solution speciation and phytoavailability of copper and zinc in soils. Environ. Sci. Technol. 36, 2645-2651.

Lasat, M.M., 2002. Phytoextraction of toxic metals: A review of biological mechanisms. J. Environ. Qual. 31, 109-121.

Leschber, R., Davis, R.D., Lhermite, P., 1985. Chemical Methods for Assessing Bio-available Metals in Sludges and Soils. Elsevier Applied Science Publishers, London.

Li, F.L., Shan, X.Q., Zhang, T.H., Zhang, S.Z., 1998. Evaluation of plant availability of rare earth elements in soils by chemical fractionation and multiple regression analysis. Environ. Pollut. 102, 269-277.

Lindsay, W.L., Norvel, W.A., 1978. Development of a DTPA soil test for zinc, iron, manganese and copper. Soil Sci. Soc. Am. J. 42, 421-428.

Lise, S.P., Erik, H.L., Poul, B.L., Preben, B., 2002. Uptake of trace elements and PAHs by fruit and vegetables from contaminated soils. Environ. Sci. Technol. 36, 30573063 . 
Mcbride, M.B., Tyler, L.D., Hovde, D.A., 1981. Cadmium adsorption by soils and uptake by plants as affected by soil chemical properties. Soil Sci. Soc. Am. J. 45, 739-744.

McGrath, S.P., 2000. Risk assessment of metals. In: Luo, Y., McGrath, S.P. (Eds.), Proceedings of SoilRem 2000, Int. Conf. of Soil Remediation, October 15-19, Hangzhou, China, pp. 1-7.

Nelson, D.W., Sommers, L.E., 1982. Total carbon, organic carbon, and organic matter. In: Page, A.L. (Ed.), Methods of Soil Analysis, Part 2. Chemical and Microbiological Properties, second ed. American Society of Agronomy, Madison, WI, pp. 539-579.

Novozamsky, I., Lexmond, Th.M., Houba, V.J.G., 1993. A single extraction procedure of soil for evaluation of uptake of some heavy metals by plants. Int. J. Environ. Anal. Chem. 51, 47-58.

Rhoades, J.D., 1982. Cation-exchange capacity. In: Page, A.L. (Ed.), Methods of soil analysis, Part 2. Chemical and Microbiological Properties, second ed. American Society of Agronomy, Madison, WI, p. 149.

Stewart, M.A., Jardine, P.M., Barnett, M.O., Mehlhoun, T.L., Hyder, L.K., Mckay, L.D., 2003. Influence of soil geochemical and physical properties on the sorption and bioaccessibility of chromium. J. Environ. Qual. 30, 129-137.
Sukreeyapongse, O., Holm, P.E., Strobel, B.W., Panichsakpatana, S., Magid, J., Hansen, H.C.B., 2002. pH-dependent release of cadmium, copper and lead from natural and sludge-amended soils. J. Environ. Qual. 31, 1901-1909.

Tessier, A., Campbell, P.G.C., Bisson, M.X., 1979. Sequential extraction procedure for the speciation of particulate trace metals. Anal. Chem. 51, 844-851.

Ure, A.M., Quevauviller, P.H., Muntau, H., Griepink, B., 1993. Speciation of heavy metals in soils and sediments. An account of the improvement and harmonization of extraction techniques undertaken under the auspices of the BCR of the Commission of the European Communities. Int. J. Environ. Anal. Chem. 51, 135-151.

Wang, Q., Dong, Y., Cui, Y., 2001a. Instances of soil \& crop heavy metal contamination in China. Soil and Sediment Contamination 10, 582-591.

Wang, Q., Dong, Y., Cui, Y., 2001b. Soil heavy metal contamination and practical approaches to remediation in some parts of China. In: Andrea, L. et al. (Eds.), Bioremediation of Inorganic Compounds. Battelle Press, Columbus, OH, pp. 113-123.

Zhang, S.Z., Shan, X.Q., 1997. The determination of rare earth elements in soil by inductively coupled plasma mass spectrometry. At. Spectra 18, 140-144. 